Cite as: Littlewood, D, Decelis, R, Hillenbrand, C \& Holt, D. (forthcoming). Examining the Drivers and Outcomes of Corporate Commitment to Climate Change Action in European High Emitting Industry, Business Strategy and the Environment, https://doi.org/10.1002/bse.2194

\title{
Examining the Drivers and Outcomes of Corporate Commitment to Climate Change Action in European High Emitting Industry
}

\begin{abstract}
Climate change is a major strategic issue for firms that also has global environmental, social and economic implications. This paper draws upon quantitative survey research to examine the drivers and outcomes of corporate commitment to climate change action in European high emitting industry. More specifically, this research examines the significance of business drivers, sustainability drivers, and stakeholder pressure, in motivating corporate commitment to climate change action in such industry. It furthermore assesses relationships between commitment and actual corporate greenhouse gas (GHG) performance. It is found that in European high emitting industry, business drivers and stakeholder pressure, but not sustainability drivers, enhance corporate commitment to climate change action, and that higher commitment leads to improved GHG performance. This paper contributes to hitherto limited empirical work on the drivers and outcomes of corporate commitment to climate change action, particularly in European industry contexts. It also contributes to advancing methodology in the field.
\end{abstract}

Key words: climate change, drivers, commitment, greenhouse gas performance, motivations, stakeholders, institutions, high emitting industry, Europe

\section{Introduction}

In his opening address at the COP21 Paris climate change talks UN Secretary-General Ban Kimoon urged attendees that if we are to tackle climate change, the world can no longer afford "indecision, half measures or merely gradual approaches" (IBT, 2016). Climate change, defined by the United Nations (UN) as "a change of climate which is attributed directly or indirectly to human activity" (UN, 1992: 7), is now widely recognised as an urgent global issue and as already having significant environmental, social and economic impacts (IPCC, 2014). Industry is a major contributor to climate change. Nearly half of the world's greenhouse gases (GHGs) are emitted either by combustion plants, during manufacturing, or in construction activities (World Resources Institute, 2014). Yet industry also has an important role to play in tackling climate change. Indeed, climate change is a major strategic issue for industry, creating both threats and opportunities (Backman et al., 2015; Sullivan \& Gouldson, 2016).

This research aims to examine what drives corporate commitment to climate change action, and whether such commitment leads to enhanced GHG performance, in European high emitting industry. More specifically, it considers the significance of business drivers (i.e. cost reduction); sustainability drivers (such as wanting to 'do the right thing'); and stakeholder pressure (e.g. demands from customers), in motivating commitment to climate change action 
in such industry. It also assesses relationships between commitment and firm GHG performance, e.g. investing in climate friendly technologies, innovating to improve energy efficiency etc. This paper draws upon empirical survey research with managers in high emitting industry throughout Europe. This study seeks to answer three research questions: (1) What drives corporate commitment to climate change action in European high emitting industry? (2) In such industry, does corporate commitment to climate change action translate into improved GHG performance? (3) What factors moderate these relationships?

This paper makes several contributions. To date, few studies have examined integratively, and using empirical data collected from practicing managers, the drivers of and outcomes from corporate commitment to climate change action. Whilst certainly scholars have considered what drives firms to adopt other types of pro-active environmental strategies (see Jansson et al., 2015; Roy et al., 2001), there remains a need to assess whether and to what extent these reasons hold in a climate change context, as well as a high emitting industry context. The work of Boiral et al. (2012) focussing on Canadian manufacturing firms represents one of few instances where drivers and outcomes of corporate commitment to climate change action have been considered together. In their work, they explicitly identify a need for additional similar research but in different regions of the world. Our study in a European high emitting industry context responds to their call. In so doing, through comparison, it also sheds light on the role contextual/institutional factors may play on dynamic relationships between drivers, outcomes and commitment to climate change action. To our knowledge, no other Europe-wide study of the kind undertaken in this research exists. Our work therefore also provides novel insights on what matters and what does not in driving corporate climate change commitment, and on whether and how commitment to climate change action translates into improved GHG performance. Finally, whilst our work draws upon that of Boiral et al. (2012), utilising their conceptual framework, it extends and develops the framework's constructs. This enhancement and our exploratory scale development represent a further significant contribution of this study, and provide insights for future scholarship.

The paper is structured as follows. We first introduce the study's conceptual framework, develop the hypotheses, and position the study in relation to extant literature. The methodology is then outlined, followed by discussion of results. We then discuss the research's key findings, before concluding with further reflection on the paper's contributions and its implications for practice, as well as identifying areas for future research.

\section{Conceptual Framework and Hypotheses}

Climate change and strategy have been the subject of increasing academic attention (see Backman et al., 2015; Kolk \& Pinkse, 2005; Lee, 2012 amongst others). Nevertheless, there remains significant scope for further enquiry. Our study contributes to understanding in one understudied area, that of the drivers and outcomes of corporate commitment to climate change action. With the exception of Boiral et al's (2012) work on Canadian manufacturing firms, to date much of the research in this area has focussed on what motivates companies to reduce their GHG emissions (e.g. Okereke, 2007; Sprengel \& Busch, 2011) but without assessing the relative significance of different factors, or indeed relationships between drivers, commitment and actual performance. There is little or no work that adopts the integrative approach employed in this paper, and which applies this in specifically European industry contexts. 
In extant literature, particularly the work of Bansal \& Roth (2000), three main drivers of corporate commitment to climate change action are often identified - business drivers, sustainability drivers, and stakeholder pressure. These drivers inform the development of our conceptual framework and hypotheses, which will now be introduced.

\section{Business Drivers}

Climate change represents a significant strategic threat to industry, but one that also brings with it opportunities (Porter \& Reinhardt, 2007). Climate change threats may be physical, for instance risk of damage to business infrastructures because of extreme weather events (Winn et al, 2011). They may be institutional, for example, additional costs of complying with new climate change regulations, or responding to government demands for climate change action (Sullivan \& Gouldson, 2016). They may also be more market based, for instance growing consumer expectation that firms take proactive climate change action, meanwhile competitors may be more responsive to such consumer sentiment and therefore gain competitive advantages. However, many of these issues may equally be viewed from a perspective of strategic opportunities. Companies can use their proactive climate change engagement as a way to differentiate their products from competitors (Walsh \& Dodds, 2017). Minimising resource use through greener production, and reducing the carbon footprint of operations, can also have benefits in terms of lowering costs (Schultz \& Williamson, 2007). Furthermore, gains can be made through strategic engagement with carbon-trading markets (Pinkse \& Kolk, 2007). In summary, and aligned with wider arguments in the sustainability literature, 'win-win' relationships can result from firms taking action on climate change, with such action good for firm financial performance as well as the environment (López-Gamero et al., 2010). Albeit these suggested positive relationships are contingent on varied factors, and are not universally accepted. Many business leaders furthermore remain sceptical about opportunities relating to climate change action, and still largely perceive such action in terms of cost (Environment Agency, 2015).

Clearly, there are business drivers in the form of responding to strategic threats, and opportunities, which may motivate firms to take action on climate change. The existence of such business drivers are widely acknowledged in the literature (see for example Bansal \& Roth, 2000; Okereke, 2007; Böttcher \& Müller, 2013 etc.). They are also included in the framework provided by Boiral et al. (2012). Interestingly, Boiral et al. (2012) in their study do not find support for a relationship between business drivers and commitment to action on climate change. They attribute this to managers not perceiving the potential financial benefits associated with GHG emission reduction initiatives, and on balance in their decision-making focussing more on the costs of such engagement. There is a need to better understand this relationship between business drivers and climate change commitment, especially in European rather than Canadian industry contexts, and from the perspective of practicing managers. It would furthermore be useful to know whether perceptions around this have changed in the intervening years since Boiral et al's (2012) study. Our research sheds light on these issues, with the above discussions informing the development of the following hypothesis: 


\section{Sustainability Drivers}

Managers may also be more personally motivated to act on environmental issues, including climate change, because they consider doing so to be the 'right thing to do' (Bansal \& Roth, 2000). This significance of personal values and beliefs in motivating proactive environmental behaviours is observed by Williams \& Schaefer (2013) in their recent study of SME owners. It is further identified by Okereke (2007) in a study of the role ethical considerations can play in motivating UK FTSE100 companies to engage in carbon management. Okereke (2007) also identifies a need for further study of the relative importance of different motivational factors in driving firm sustainable behaviours, as well as of the link between motivations and actual firm responses, both of which we address in this paper.

In this study, these more personal motivations for engaging in sustainable behaviours, and more specifically action on climate change, are regarded as sustainability drivers. Other sustainability drivers include garnering employee involvement, for example Bansal (2002) identify the importance of engendering a sustainable development 'mind-set' within organisations, and amongst key stakeholders, to galvanise corporate managerial commitment to and engagement with, sustainability. Also considered sustainability drivers are positive attitudes towards pro-environmental behaviours and environmental stewardship in top management, and company headquarters, which can filter down and normatively drive more sustainable behaviours elsewhere in organisations, as well as in subsidiaries (see Ervin et al, 2012; González-Benito \& González-Benito, 2006; Halkos \& Evangelinos, 2002).

In the study by Boiral et al. (2012), what we call sustainability drivers are titled as 'social and environmental' motivations. Boiral et al. (2012) find a significant positive association between such motivations and commitment to climate change action. However, beyond their study, little empirical work has examined the relationship between sustainability drivers and commitment to action on climate change. Further research is needed to confirm or dispute Boiral et al.'s (2012) findings, as well as to establish the nature of this relationship in alternate industry and institutional settings. This leads to our second hypothesis:

\section{H2: Sustainability drivers positively influence corporate commitment to climate change action}

\section{Stakeholder pressure}

Stakeholders may exert pressure on firms to engage in pro-environmental activity (Delmas \& Toffel, 2004; Haddock-Fraser \& Tourelle, 2010), including potentially influencing their commitment to, and action on, climate change (see Okereke, 2007; Jeswani et al., 2008, Dögl $\&$ Behnam, 2015). Adopting an institutional theory perspective (Scott, 2001), this pressure may be coercive and require adherence to government laws and regulations by organisations in order to gain and retain legitimacy (Jeswani et al., 2008). Formalised rules and associated practices may also originate from corporate headquarters which subsidiaries in other parts of the world are required to adopt. However, other stakeholder groups may also exert pressure, of different kinds, on firms for climate change action. This may include more normative pressure, like that from consumers who increasingly expect companies to be responsive to sustainability issues, with the degree of responsiveness influencing their purchasing decisions (Haddock-Fraser \& 
Tourelle, 2010). Environmental groups may also campaign for corporate action on climate change (Delmas \& Toffel, 2004; Sprengel \& Busch, 2011), and legitimise or delegitimise firms and their sustainability actions. Employees can also exert pressure for engagement with sustainability through being more attracted to, and engaged within, firms demonstrating sustainability values and leadership. There is furthermore evidence that financial markets and investors increasingly expect business to engage with climate change (Kolk \& Pinkse, 2007). Finally, pro-active strategic engagement by competitors with sustainability, and climate change more specifically, can force firm action. This can even shift organisational fields, whereby engagement with the sustainability agenda becomes cognitively taken for granted amongst organisations and their managers, and part of the threshold to compete in an industry.

Institutional theory has been widely deployed in explaining how stakeholders may influence firms to engage in pro-environmental behaviours (see Dögl \& Behnam, 2015), and more specifically to take action on climate change (Delmas \& Montes-Sancho, 2010). This includes in the work of Boiral et al. (2012) who note that institutional systems of governance in particular countries influence the extent, type of, and mechanisms through which pressure is exerted on firms to reduce their GHG emissions. In explaining our results later in this paper, we therefore draw upon institutional theory. Based on the preceding discussions we propose the following hypothesis:

\section{H3: Stakeholder pressure positively influences corporate commitment to climate change action}

\section{Transforming corporate commitment into action}

Firms can take a range of actions to improve their GHG performance, for instance improving energy and process efficiencies, reducing fossil fuel consumption, innovating to develop lowcarbon technologies etc. Some firms, particularly in the energy sector, also opt for 'transition technologies' such as carbon capture and storage. Why firms respond differently to climate change has received some attention in the literature, for example Lee (2012) examines corporate carbon strategies in Korean firms identifying six strategy types. Meanwhile, Lee \& Klassen (2015) examine this question focussing on the role of external business uncertainty and internal organisational capabilities. Across the environmental management literature as a whole, authors have furthermore considered the drivers of and benefits from proactive versus more reactive environmental strategies (see for example Wakabayashia \& Arimurac, 2016). Clearly, commitment to action on climate change is translated into practice in varied ways, with context and institutional variability significant in explaining observed differences. For example, recent work by Backman et al. (2015) contrasts climate change strategies amongst European and North American companies, finding that whilst European firms are doing better in areas of governance, information management, and systems, North American firms are doing as well or better in actual technology-related investments. Together, this literature informs the development of our GHG commitment construct.

However, our study is also concerned with the relationship between commitment and actual GHG performance. The literature on firm environmental performance is extensive (see Bhattacharyya \& Cummings, 2015) with some more specific attention also given to climate change performance (e.g. Leisen, 2015). Nevertheless, and as noted by Boiral et al. (2012) work on the determinants of GHG performance in companies remains scarce. Boiral et al. 
(2012), amongst others (e.g. Furrer et al. 2012), further observe that many companies only take symbolic or superficial actions to address climate change, with limited overall impact on their actual GHG performance. Engagement in pro-environmental behaviours by subsidiaries, under pressure from headquarters, is also often only partial or diluted, and influenced by local institutional factors (Jamali, 2010). In this paper, we therefore assess the relationship between corporate commitment to climate change action and actual GHG performance, proposing the following hypothesis:

H4: A company's level of commitment to reducing GHG emissions positively influences its GHG performance

\section{Contextual Factors}

How, and to what extent firms respond to pressure from stakeholders, sustainability drivers, and business related drivers, may be influenced by various contextual factors. It may vary by sector and industry (Jeswani et al., 2008). For example, Haddock-Fraser \& Tourelle (2010) find that close-to-consumer companies are more active in certain types of environmental management activity owing to their proximity to consumers, and associated imperatives for reputation management. Lee (2012) meanwhile, finds a statistically significant relationship between types of carbon strategy and sector in a Korean sample.

Facility size is another commonly identified contextual factor, with some studies finding larger firms to be more committed to environment action and demonstrating superior environmental performance (e.g. López-Gamero et al., 2010). Other contextual factors include country differences. For example, regulations and policy in relation to climate change may differ with varying levels of strictness, enforcement, or incentives (Kolk \& Pinkse, 2008; Jeswani et al., 2008 etc.). The extent and manifestation of stakeholder pressure may also vary nationally, whilst managerial attitudes towards climate change may also differ (Cummings, 2008). Unpacking this potential for inter-country difference is part of the rationale for, and contribution of, our study.

A further contextual factor is that of current firm emissions levels. Yalabik \& Fairchild (2011) suggest that above certain emissions levels stakeholder pressure may in fact have an adverse effect on a firm's environmental investment. Similarly, Sprengel \& Busch (2011) find that an organisation's level of emissions measured as its GHG intensity has an influence on its environmental strategy, suggesting that companies with the highest GHG intensity often look to either avoid stakeholder pressure, or increase permitted emissions limits, rather than radically reduce GHG emissions through fundamentally rethinking their business models.

Whilst these contextual factors are far from exhaustive, they are used in our study to identify three control variables: country, facility size and current emissions level. Institutional variability, and industry variability, are further considered through comparison of our study of firms in European high emitting industry with Boiral et al's (2012) work on Canadian industry.

Based on the preceding discussions, and informed by the work of Boiral et al. (2012), a conceptual framework linking the drivers and outcomes of corporate commitment to climate change action is proposed (Figure 1). This framework integrates the four hypotheses and three control variables. 


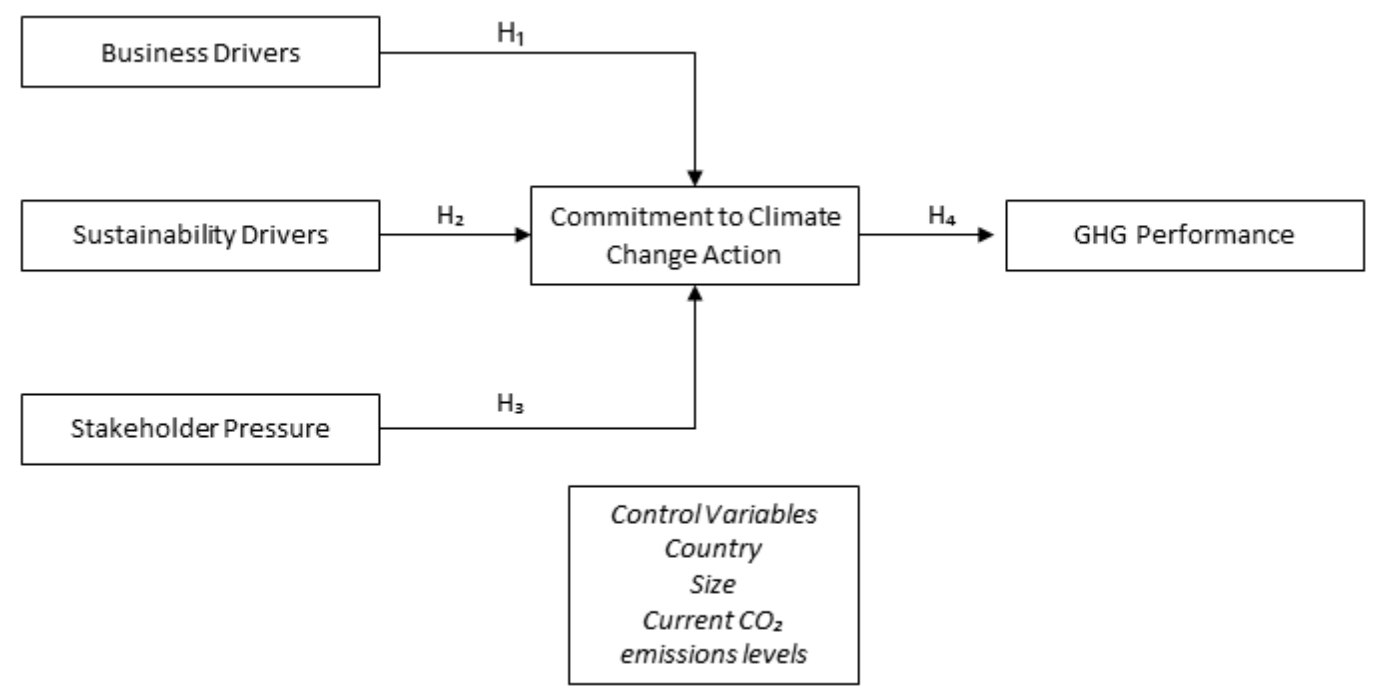

Figure 1: Conceptual Model

\section{Methodology}

Study context and sampling

The context for this research is European high emitting industry. Respondents were accordingly drawn from two high emitting industrial sectors - large combustion and chemical manufacturing - from across 27 EU members states (in 2012), Switzerland and Norway. We focus on high emitting industry because of the significant contribution such industry makes to EU GHG emissions. In respect of the two industries selected, large combustion plants emitted $31 \%$ of the EU's 3.7 billion tonnes of $\mathrm{CO}_{2}$ in 2012, whilst industrial chemical plants emitted a smaller but still significant $2.7 \%$ (EEA, 2014). The unit of analysis for this research is the individual facility as it is the organisational level at which emissions occur. The sample was identified using the European Pollutant Release and Transfer Register (E-PRTR) database. At the time of this research, the most recent data available was for the year 2012, this was therefore chosen as the reference year. During 2012, 938 large combustion plants and 203 chemical plants reported their $\mathrm{CO}_{2}$ emissions to the E-PRTR database, giving a total sample for the research of 1,141 facilities.

Data collection occurred using an electronic survey. Out of the original sample of 1,141 facilities 71 could not be reached. In November 2014, the questionnaire was sent to 42 facilities for pilot testing, no significant problems were identified. In December 2014, it was then rolled out to the remaining facilities. Out of the 1,070 facilities contacted, 93 full responses were 
received, mostly completed by environmental managers (Appendix A presents a description of the sample). The response rate was somewhat low at $8.7 \%$. Nevertheless, we feel gaining data from almost 100 respondents in two high emitting industrial sectors was a significant accomplishment, and further underlines our study's value.

\section{Measures}

As identified previously, quantitative empirical research, particularly utilising data directly from practicing managers, on the drivers of and outcomes from corporate commitment to climate change action remains scarce. Accordingly, there is a need for significant conceptual and methodological refinement and development. In selecting the measures for our constructs, we therefore adopted an exploratory approach. We took elements from a range of literatures and existing instruments, with the aim of better understanding what elements matter and which do not in the context of drivers and outcomes of corporate commitment to climate change action, as well as to enhance the measurement of the constructs in our model (see Figure 1).

The 'Business drivers' construct was measured using nine elements. Five of them were derived from the instrument used by Boiral et al. (2012). A further three were taken from the work of Okereke (2007) - reducing risk, developing leverage in climate policy, and increasing profits. A final element identified was innovation in response to climate change as a source of additional revenue and profits, informed by the work of Kolk \& Pinkse (2005). The extent to which business drivers mattered in motivating commitment to climate change action was assessed on a five point scale ( $1=$ no influence at all, $5=$ very strong influence).

To measure the 'Sustainability drivers' construct we used the seven elements identified by Boiral et al. (2012) which we considered quite exhaustive and well-grounded in the literature (see Jeswani et al., 2008; Okereke, 2007). A five-point influence scale was used in the same way as for 'Business drivers'.

Informed by the approach of Kassinis \& Vafeas (2006) a list of relevant stakeholders was compiled from the literature, consisting of stockholders, company owners, corporate headquarters, facility management, employees, customers, suppliers, competitors, financial institutions and insurance companies, government, regulatory authorities, the general public, environmental groups, and the media (Jeswani et al., 2008; Boiral et al., 2012). Respondents were asked to what extent their facility was under pressure to reduce its GHG emissions from these different groups.

The 'Commitment to climate change action' construct was measured drawing partly upon Boiral et al.'s (2012) GHG commitment construct. Three of Boiral et al.'s (2012) elements were included, with a fourth relating to whether a facility supported the Kyoto Protocol excluded, reflecting the different institutional context of the EU where there are legally binding requirements around this. However, additional elements were also included. These were: consideration of GHG performance in the strategic planning process (after Judge \& Douglas, 1998); incorporating climate change in the company's culture, and integrating GHG targets in management control systems (both drawing upon Arjaliès \& Ponssard, 2010); having an environmental policy that includes a commitment to GHG reduction (Dechant \& Altman, 
1994); benchmarking against others in the same sector (Jeswani et al., 2008); and giving importance to GHG emissions across the supply chain (Jayachandran et al., 2013). The inclusion of these additional elements develops Borial et al's (2012) work, and provides a fuller measure of climate change commitment. Respondents were asked to identify, on a five-point scale from strongly disagree to strongly agree, the extent to which statements pertaining to the above elements described their facility's commitment to reducing GHG emissions.

To measure 'GHG performance' respondents were asked to rate the environmental performance of their facility over the past three years relative to others in their sector. Items to assess GHG performance were drawn from Boiral et al.'s (2012) study, but also wider work. Boiral et al.'s (2012) construct contained only three items (regulatory compliance, air emission levels, and GHG emissions). However, we considered air emissions too broad as a measure of GHG performance, since it encompasses non-GHG pollutants, so it was excluded. Additional elements incorporated into the measurement of GHG performance were: going beyond compliance (Judge \& Douglas, 1998); improving process efficiency (Porter \& van der Linde, 1995); reducing fossil fuel consumption (Jeswani et al., 2008); investing in renewable energy; innovating to meet environmental objectives (Kolk \& Pinkse, 2005), and supporting research on low-carbon products or technologies.

Lastly, and as explained earlier, three control variables were identified. These were: country, respondents were asked which country their facility was located in; facility size, measured using number of employees, as is typical in other studies; and current emissions level, with respondents also asked to select their annual level of $\mathrm{CO}_{2}$ emissions, and whether they felt their level of GHG emissions in comparison to others influenced their GHG commitment.

The final research instrument contained one reflective ('Commitment to climate change action') and four formative ('Business drivers', 'Sustainability drivers', 'Stakeholder pressure' and 'GHG performance') scales. A full list of scale items is provided in Appendix B, together with item weights for the formative scales and item loadings for the reflective scale. As can be seen in Appendix B a number of formative indicators emerged as non-significant, most likely due to our goal in this study to develop wide-ranging scale items, given the exploratory nature of the research. We therefore ran our final model, both with and without these non-significant indicators, and results for both models are reported in the results section. Interestingly, the two path models suggest almost identical results, so that non-significant indicators were retained in the model to provide researchers with a full insight into the variety of themes that did and did not matter to respondents in this study. We believe this will be helpful for future researchers developing scales in this area.

\section{Analysis}

Standard checks concerning assumptions of normality, missing values and outliers were conducted with the data, resulting in a final dataset containing 93 respondents. No outliers were removed but two partially complete responses were noted and marked as 'missing data' for analysis. Harman's single factor test was performed as a post-hoc analysis of common method bias. This procedure revealed the presence of distinct factors in the un-rotated factor solution. While these results do not preclude the possibility of common method variance, they suggest that it is not a likely explanation for the reported findings. Due to the predictive nature of this 
research study, as well as the presence of both formative and reflective indicators, we adopted a partial least squares structural equation modelling approach (PLS-SEM) using SmartPLS. Following the procedure outlined by Hair, Ringle \& Sarstedt (2011), we applied a two-stage assessment of the proposed model, before checking for the influence of control variables.

In stage one we assessed validity and reliability of the outer model. For the four formative indicator scales, this includes bootstrapping to test for significance of the indicators' outer weight coefficients, as well as testing for significance of the indicators' loadings. Together, these tests provide a measure of each indicator's relative usefulness in explaining the latent construct (Cenfetelli \& Bassellier, 2009). For the reflective indicator scale, composite reliabilities was assessed against the expected score of 0.7 , and convergent validity evaluated through average variance extracted (AVE), while discriminant validity was evaluated through indicator cross-loadings and the Fornell-Larcker criterion (Fornell \& Larcker, 1981). Furthermore, the variance inflation factor (VIF) provides information about possible redundant variables demonstrated by high levels of multicollinearity (Henseler et al., 2009).

Stage two assessed the inner model by examining the $\mathrm{R}^{2}$ values for each latent variable in the model, sign, magnitude and significance of path coefficients (Henseler et al., 2009), effect size $\left(\mathrm{f}^{2}\right)$ of predictor variables (Cohen, 1988), and predictive relevance of the model $\left(\mathrm{Q}^{2}\right)$, using blindfolding to obtain cross-validated redundancy measures. To check for other potential systematic differences, we divided the scale for each of the control dimensions (size, $\mathrm{CO}_{2}$ emissions and country). For size and $\mathrm{CO}_{2}$ emissions, we created high and low groups, and for the country dimension, we distinguished between 'EU15' member states ${ }^{1}$ and others. We then conducted group comparisons with the dichotomized moderators (Henseler \& Fassot, 2009). The path coefficients for the subsamples for each dimension were compared using bootstrap analysis and significant differences measured by pair-wise t-tests identified moderating effects.

\section{Results}

Our assessment of the research model in terms of its outer measurement reveal significant $(p<0.01)$ loadings for all reflective indicators belonging to the "Commitment to climate change action' scale, ranging from 0.618 to 0.820 , and a satisfactory composite reliability score of 0.913. The AVE is 0.549, thereby exceeding requirements of 0.5 (Hair et al., 2011). Discriminant validity is satisfactory as the square root of the 'Commitment to climate change action' variable's AVE (0.742) emerges greater than the variance shared by the other constructs and their opposing construct (with the exception of a high latent variable correlation between 'Business drivers' and 'Sustainability drivers'), as shown in Table 1. The high correlation between 'Business drivers' and 'Sustainability drivers' will be discussed under limitations of this study, but it should be noted here that 'Sustainability drivers' did not emerge as a significant factor in 'Commitment to climate change action' (see below), and as its inclusion or exclusion did not alter final results significantly, it was retained in the model to fully disclose all findings. Importantly, despite the fact that a number of formative indicators emerged as nonsignificant, all formative indicators are retained in the model as the assessment of both weights and loadings confirm all are significant on at least one if not both criteria. While not displayed

\footnotetext{
${ }^{1}$ EU15 refers to the composition of the EU before a significant expansion in 2004. The EU15 member states are Austria, Belgium, Denmark, Finland, France, Germany, Greece, Ireland, Italy, Luxembourg, Netherlands, Portugal, Spain, Sweden and the United Kingdom
} 
in Appendix A, it should be noted that all formative indicators with the exception of one item from the 'Stakeholder pressure' scale (customers), emerged with significant item loadings. In addition, as explained in earlier parts of this paper, this empirical study was conducted with an exploratory mind-set, hence the inclusion and display of all items, whether they emerged as significant or not, is seen as an important contribution of this study to aid further scale development in this research area. The VIF values are within the acceptable range of five or less (Hair et al., 2011). 
Table 1. Descriptive information and latent variable correlation matrix

\begin{tabular}{|c|c|c|c|c|c|c|c|c|}
\hline $\begin{array}{l}\text { Latent } \\
\text { variables }\end{array}$ & Mean* & $\begin{array}{r}\text { Std } \\
\text { dev. }\end{array}$ & $\begin{array}{l}\text { Composite } \\
\text { reliability }\end{array}$ & $\begin{array}{l}\text { Business } \\
\text { drivers }\end{array}$ & $\begin{array}{c}\text { Sustainability } \\
\text { drivers }\end{array}$ & $\begin{array}{l}\text { Stakeholder } \\
\text { pressure }\end{array}$ & $\begin{array}{c}\text { Commitment to } \\
\text { climate change } \\
\text { action }\end{array}$ & $\begin{array}{c}\text { GHG } \\
\text { performance }\end{array}$ \\
\hline Business drivers & 2.799 & .711 & $\overline{\text { (formative) }}$ & (formative) & & & & \\
\hline $\begin{array}{l}\text { Sustainability } \\
\text { drivers*** }\end{array}$ & 3.046 & .751 & (formative) & $.748 * * * *$ & (formative) & & & \\
\hline $\begin{array}{l}\text { Stakeholder } \\
\text { pressure }\end{array}$ & 2.619 & .698 & (formative) & .441 & .559 & (formative) & & \\
\hline $\begin{array}{l}\text { Commitment to } \\
\text { climate change } \\
\text { action }\end{array}$ & 3.697 & .664 & .911 & .564 & .558 & .609 & $.742 * *$ & \\
\hline $\begin{array}{l}\text { GHG } \\
\text { performance }\end{array}$ & 3.444 & .524 & (formative) & .299 & .200 & .301 & .533 & (formative) \\
\hline
\end{tabular}

* Mean scores for each summated scale are based on a Likert-type scale ranging from 1 to 5 .

** Value represents square-root of AVE (discriminant validity measure for reflective variables).

*** Scores for 'Sustainability drivers' are shown in cursive, as concept emerged as non-significant in overall research model.

**** Latent variable correlation between 'Sustainability drivers' and 'Business drivers' is noticeably large, which is discussed in methodology and limitations. 'Sustainability drivers', however, does not have a significant path coefficient to 'GHG commitment', hence plays a non-significant role in the overall model and is retained solely for reasons of comprehensiveness. 
Turning now to the assessment of the inner model, Figure 2 reveals moderate $(0.277)$ to substantial (0.576) effect sizes for the endogenous latent variables 'GHG performance' and 'Commitment to climate change action' respectively (Chin, 1998). Analysis of path coefficients reveals two relationships supported at $\mathrm{p}<0.01$ ('Stakeholder pressure' 'Commitment climate change action' and 'Commitment to climate change action' - 'GHG performance'), one supported at $\mathrm{p}<0.05$ (Business drivers' - 'Commitment to climate change action') and one non-significant relationship ('Sustainability drivers' - 'Commitment to climate change action'). Test of explanatory power of the model utilizing $\mathrm{f}^{2}$-tests suggests small to moderate effect sizes of predictor variables (Chin, 1998). The sample reuse measure $\mathrm{Q}^{2}$ confirms the predictive relevance of all exogenous constructs on their related endogenous constructs.

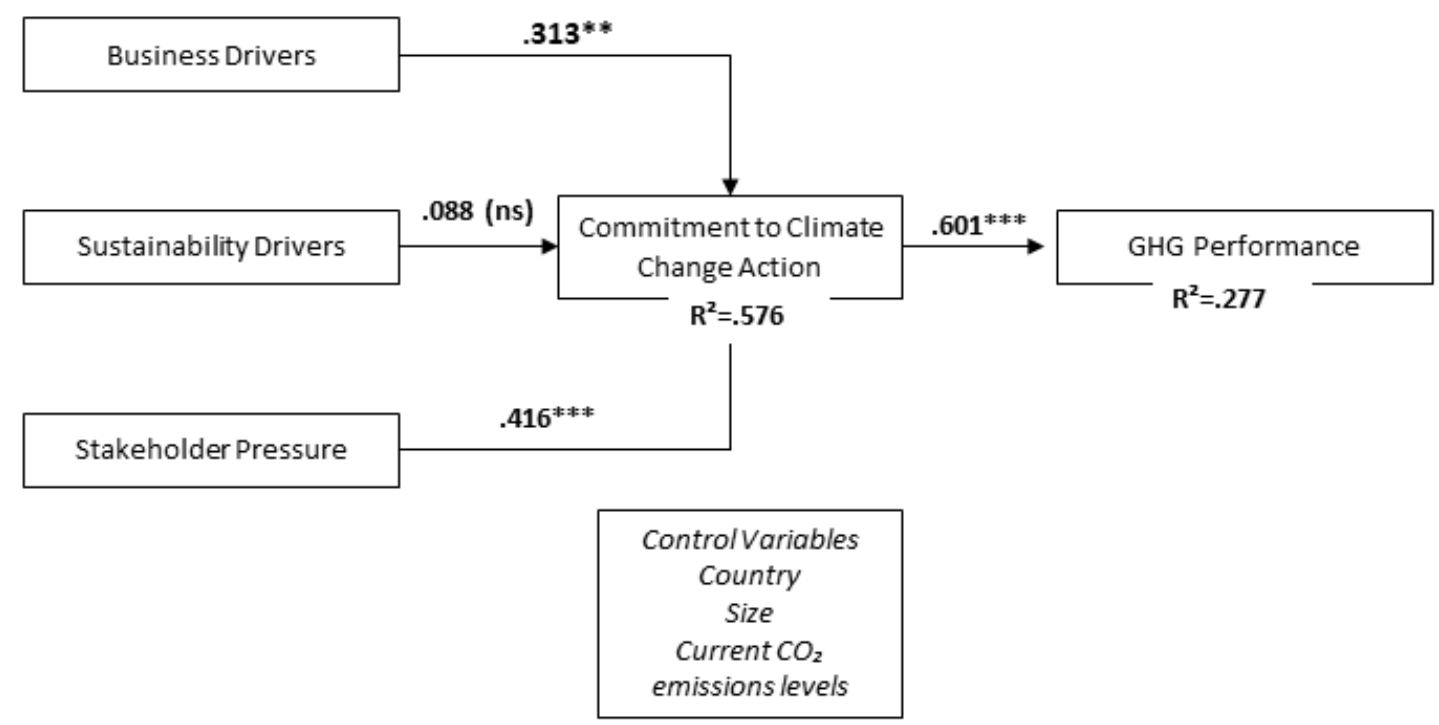

Figure 2: R2 and path coefficients for model

In testing the impact of control variables, group comparisons using PLS-SEM multi-group analysis reveal significant group differences for only one of the control variables $\left(\mathrm{CO}_{2}\right.$ emissions), while the remaining two (size and country) display no significant differences. The results for $\mathrm{CO}_{2}$ emissions indicate significant differences in two path linkages between respondents who answer for facilities equal or below 500,000 tonnes and respondents who answer for facilities above 500,000 tonnes: from 'Stakeholder pressure' to 'Commitment to climate change action' $(\beta$ low $=0.513, \beta$ high $=0.364, \mathrm{p}<0.05)$, and from 'Commitment to climate change action' to 'GHG performance' ( $\beta$ low $=0.788, \beta$ high $=0.634, \mathrm{p}<0.05)$. Interestingly, and in contrast to what might be expected, this suggests that respondents from facilities with lower $\mathrm{CO}_{2}$ emissions perceive a stronger link between stakeholder pressure and company commitment to climate change action, and equally between such commitment and GHG performance. Table 2 provides a summary of multi-group analyses with control variables. 
Table 2. Group differences in path coefficients for control variables (bootstrapped means)

\begin{tabular}{|c|c|c|c|c|c|c|c|c|c|}
\hline \multirow[b]{2}{*}{ Model paths } & \multicolumn{3}{|c|}{ Size } & \multicolumn{3}{|c|}{ Country } & \multicolumn{3}{|c|}{$\mathrm{CO}_{2}$ emissions } \\
\hline & $\begin{array}{c}1=<200 \\
\text { employees }\end{array}$ & $\begin{array}{l}2=\geq 200 \\
\text { employee }\end{array}$ & $p$ & $\begin{array}{c}1= \\
E U 15\end{array}$ & $\begin{array}{c}2= \\
\text { Other }\end{array}$ & $p$ & $\begin{array}{c}1= \\
\leq 500,000 \\
\text { tonnes }\end{array}$ & $\begin{array}{c}2= \\
>500,000 \\
\text { tonnes }\end{array}$ & $p$ \\
\hline $\begin{array}{l}\text { Business drivers } \rightarrow \text { Commitment to climate } \\
\text { change action }\end{array}$ & .264 & .402 & ns & .419 & .257 & ns & .288 & 287 & ns \\
\hline $\begin{array}{l}\text { Sustainability drivers } \rightarrow \text { Commitment to } \\
\text { climate change action }\end{array}$ & .217 & .090 & $\mathrm{~ns}$ & .171 & .106 & $\mathrm{~ns}$ & .149 & .278 & ns \\
\hline $\begin{array}{l}\text { Stakeholder pressure } \rightarrow \text { Commitment to } \\
\text { climate change action }\end{array}$ & .419 & .474 & $\mathrm{~ns}$ & .377 & .549 & $\mathrm{~ns}$ & .513 & .364 & $* *$ \\
\hline $\begin{array}{l}\text { Commitment to climate change action } \rightarrow \mathrm{GHG} \\
\text { Performance }\end{array}$ & .788 & .654 & ns & .723 & 678 & ns & .788 & .634 & $* *$ \\
\hline
\end{tabular}




\section{Additional model test taking account of non-significant formative indicators}

A number of formative indicators emerged as non-significant, see Appendix A. As outlined earlier, due to limited existing empirical measurement in the field of study, we developed wideranging scale items, approaching the measurement of our constructs from an explorative lens. As such, it was an explicit aim of this study to set out and test a wide variety of elements in our constructs. However, in order to ensure that the inclusion of non-significant formative indicators does not distort our results, we ran the final analysis without these non-significant indicators (Hair et al., 2011). Interestingly, this analysis reveals almost identical results to the results displayed above. The path coefficients for an alternative model excluding any nonsignificant formative indicators were as follows: 'Business drivers' to 'Commitment to climate change action' $0.342 * * *$ (previously $0.313 * *$ ), 'Sustainability drivers' to 'Commitment to climate change action' $0.049 \mathrm{~ns}$ (previously $0.088 \mathrm{~ns}$ ), 'Stakeholder pressure' to 'Commitment to climate change action' $0.380^{* * *}$ (previously $0.416^{* * *}$ ), and 'Commitment to climate change action' to 'GHG performance' $0.561 * * *$ (previously $0.601 * * *$ ). Adjusted R-squared values for 'Commitment to climate change action' emerged as 0.461 (previously 0.576) and for 'GHG performance' 0.318 (previously 0.277 ). We thus concluded that rather than excluding these indicators from our analysis and model, it would be useful for other researchers to inspect our full data analysis and model.

\section{Discussion}

The empirical data supports the overall validity and predictive relevance of our conceptual framework of drivers and outcomes of climate change commitment. Through the development and validation of our statistical model, we have also been able to address the study's aim and research questions. Overall, H1 is supported. In the perception of the managers surveyed, business drivers positively influence commitment to climate change action. As identified in the literature review there is now extensive work, conceptual and empirical, as well as a wider narrative, identifying a 'win-win' business case for firms to engage with sustainability, including take action on climate change (Henri et al., 2014; Okereke, 2007; López-Gamero et al., 2010). It seems that overall such arguments find traction in a European industry context. This is in contrast to the findings of Boiral et al.'s (2012) study in Canada, where business drivers were not found to influence corporate commitment to climate change action. However, further analysis of our results reveals a more complex picture.

First, the business driver 'increasing profits' appeared as a statistically significant negative indicator, suggesting that managers in European industry do not see a clear link between action on climate change and increasing profits. Our sample regarded such action as detrimental to profitability, at least in the short-term. This sceptical attitude towards a short-term business case for climate action persisted in elements like 'marketing/advertising opportunity' and 'access to capital', which whilst non-significant, were negative. Interestingly, all of the business driver items taken from the Boiral et al. (2012) study were non-significant in our work, supporting the findings of their study. However, the three remaining new elements added to the business driver measure - 'increasing revenue through innovation', 'reducing the risk of physical damage from the effects of climate change', and 'developing credibility and leverage to influence climate policy' all came back as statistically significant positive indicators. In our view, these latter three elements are associated with a longer-term perspective on the benefits for business of climate change action. This suggests that whilst managers in European industry 
are sceptical of short-term business case rationales, they recognise the significant longer-term risks and opportunities climate change poses.

These findings support our efforts to extend the 'business drivers' measure, by adding a longerterm perspective. They furthermore hint at geographic differences in the significance of business drivers, and it may be that the 'business case for sustainability' (Hockerts, 2015) may be more widely accepted in European industry contexts versus Canadian ones. Significant further research, applying at least the additional elements from our study, would be required to establish this more definitively.

$\mathrm{H} 2$ is not supported. Sustainability drivers do not positively influence corporate commitment to climate change action. This is in contrast to the findings of Boiral et al. (2012) who found that commitment to action on climate change was "primarily motivated by environmental and social concerns" (p. 507). In explaining this result, it is important to note first that discriminant validity was not found between 'Business drivers' and 'Sustainability drivers'. Whilst conceptually the differences between these constructs make sense, on reflection operationally the elements and scale items used may have been too similar. Nevertheless, this difference found in comparison to Boiral et al.'s (2012) study of Canada might again suggest an institutional/contextual influence. Extant work comparing CSR in Europe and the USA might help us to understand these differences. In their work, Matten \& Moon (2008) suggest that firms and managers in the USA are more 'explicit' in their engagement, and in the language used to describe their commitments to CSR, compared to their European counterparts. CSR in a European context is something more 'implicit' that is less readily expressed in the language of CSR. Whilst Canada, the focus of Boiral et al.'s (2012) study, is clearly different from the USA, at the time of their study in 2008 Canada had no binding regulation on climate change. Therefore, a more 'explicit' context existed, in which it would perhaps be logical for commitment to climate change action in firms to be driven most by environmental and social concerns, or at least for it to be framed as such by managers. However, in Europe in 2014, action on climate change is legislated. Therefore, in this context sustainability drivers, and appeals to managerial ethics, may be less necessary or relevant.

This significance of government and regulator stakeholders, that through legislation exert pressure on firms to engage in climate change action, is shown in relation to H3. Overall, it was found that stakeholder pressure positively influences corporate commitment to climate change action. However, further unpacking of these results identifies the government, and lawmakers/legislators, as the key most significant stakeholder group in explaining them. This provides support for the previous analysis in relation to 'sustainability drivers' in a European context, and aligns with the earlier finding of 'developing credibility and leverage to influence climate policy' as being a significant 'business driver'. It seems clear that formal external institutional pressures are a significant driver of commitment to climate change action in the context of European high emitting industry. Interestingly results also identify 'Environmental groups' as a significant source of stakeholder pressure, perhaps linked to their ability to influence regulators and wider stakeholders.

However, not only external stakeholders exert pressure on firms to commit to action on climate change; some internal stakeholders are also significant. Our results first identify a role for employees in driving commitment to climate change action. This might manifest in the form 
of employees demonstrating environmental leadership and spearheading positive climate change actions. There may also be a more normative influence, whereby pressure is exerted by current and future employees who expect firms to engage with climate change and wider social responsibility issues. Management and corporate headquarters were also identified as exerting pressure on firms to commit to action on climate change. This occurs through intraorganisational institutional fields, and associated rules and norms - in relation to climate change commitment and action - which are devised and disseminated within corporations (Kostova \& Roth, 2002). A final point is the non-significance of pressure from both the customer and stockholders. This finding aligns with earlier results suggesting the nonsignificance of 'business drivers' around creating shareholder/stockholder value, and addressing customer requirements. This again suggests that short-term 'win-win' arguments for climate change action are viewed quite sceptically by managers. The non-significance of customer requirements and pressure might also reflect the nature of the industries studied. Additional research is required to assess whether this is still the case in other industries, particularly those closer to consumers (Haddock-Fraser \& Tourelle, 2010).

Our final hypothesis concerned the relationship between commitment to climate change action and actual GHG performance. H4 was supported. Therefore, a company's level of commitment to reducing GHG emissions positively influences its GHG performance. Firms with higher levels of commitment to climate change action perceived that they were: more likely than others in their sector to go beyond compliance levels in limiting their GHG emissions; working more to improve operational efficiency to reduce emissions; and that they more extensively supported research on products and technology to minimise emissions. However, potentially more radical, and costly, steps like investing in renewable technologies, reducing fossil fuel consumption, and working to reduce GHG emissions in supply chains were not supported. This finding also resonates with wider literature, with corporate action on sustainability (Dyllick \& Hockerts, 2002), and more specifically climate change (Kolk \& Pinkse, 2005), often suggested as being insufficient, grounded in arguments of 'eco-efficiency', and constrained by an emphasis on the 'business case' (Hockerts, 2015). A final result to note was the negative statistically significant score for the item 'levels of GHG emissions'. We interpreted this result as most likely reflecting a misunderstanding of the question - see later discussion of limitations. It seems illogical that higher commitment to action on climate change would result in GHG emissions performance being perceived as below that of others in the industry. In this instance, we think it likely that respondents answered this question as a lower score equating to lower emissions.

It is finally necessary to comment on our control variables. As identified, significant group differences were only found for the $\mathrm{CO}_{2}$ emissions variable. The remaining two (size and country) displayed no significant differences. In the case of $\mathrm{CO}_{2}$ emissions, respondents from facilities with lower $\mathrm{CO}_{2}$ emissions perceived a stronger link between stakeholder pressure and commitment to climate change action, and equally between such commitment and GHG performance. These results can perhaps be understood that facilities with lower current GHG emissions levels are those that have been most conscious of, and subject to, stakeholder pressure, which has in turn increased their commitment to climate change action leading to better GHG performance. In respect of the country variable, whilst we found no significant difference between original EU15 member states and other countries this was not unexpected. There is considerable institutional congruence between the EU15 and these wider countries, 
and certainly more than between the EU and Canada - the focus of the Boiral et al (2012) study. In relation to size, this also was not unexpected, whilst there is some evidence in the literature that larger firms may be more committed to environment action (López-Gamero et al., 2010), this has not been definitively shown and is contingent on various factors.

\section{Conclusion}

This paper has examined the drivers of and outcomes from corporate commitment to climate change action in European high emitting industry. We have found that in this context 'business drivers' and 'stakeholder pressure', but not 'sustainability drivers', are significant drivers, and that higher levels of commitment lead to improved GHG performance, albeit there are still limits to the depth of corporate action on climate change. Finally, these relationships are moderated by the current emissions levels of facilities, but not their size or their country - at least in an intra-European context.

Throughout, we have discussed our findings in relation to those of Boiral et al. 's (2012) study. Our conceptual framework builds upon their work, albeit extending the measurement of key constructs. The justification for our study, and its contributions, can also be partly understood in relation to their call for more work examining the drivers and outcomes of corporate commitment to climate change action in different global regions. We find interesting similarities but also differences with the findings of Boiral et al. 's (2012) study. Whilst in their work 'business drivers' were not found to be significant in motivating firm climate change commitment, in ours they were, and vice versa in relation to sustainability drivers. Both studies find support for stakeholder pressure as a motivator, and that higher levels of commitment lead to improved GHG performance. We argue that at least in part these different results may be linked to institutional differences between Canada and Europe. In Europe, corporate action on climate change is more strongly mandated and regulated. As a result, a key 'business driver' for action on climate change, which was found to be significant, related to credibility and leverage to influence climate policy. It seems that managers in a European context accept the presence of regulation and government policy interventions on climate change, and want to optimise their engagement with this. In contrast, in Canada at the time of Boiral et al.'s (2012) study there were no mandatory regulations on reducing GHG emissions. In this context, it is understandable that sustainability drivers, like wanting to 'do the right thing' come more to the fore. In Europe, in 2014, climate change action may relate less to individual morality and ethics and is more an accepted part of doing business.

Our efforts to enhance the measurement of the constructs in our conceptual framework are a further significant contribution of this research. As identified previously, the limited number of existing studies examining empirically, and integratively, the drivers and outcomes of corporate commitment to climate change action necessitated the exploratory inclusive approach to scale development adopted. It is hoped that our transparency in data analysis will provide insights for other researchers, both in terms of the identification of seemingly nonsignificant items and new items that allow for better measurement of constructs. For example, the more long-term oriented items included to assess the role of 'business drivers', and the extra items included measuring corporate commitment to climate change action and GHG performance. 
This study furthermore contributes to knowledge about the drivers and outcomes of commitment to climate change action in a European high emitting industry context. To our knowledge, no other integrative study of this kind focussing on European industry has been conducted. It seems that in European high emitting industry, 'business drivers' matter, but only if managers adopt a long-term perspective recognising the need for climate change action to mitigate legislative and physical risks, and to gain competitive advantage through long-term innovation. Currently managers in European industry remain sceptical of the short-term 'business case' for climate change action. These findings have implications for European policy makers, who are themselves regarded by firms as key stakeholders in relation to climate change action, more so than customers or shareholders. Our results on GHG performance also indicate that the extent of corporate action on climate change remains constrained, providing further insight for policy makers looking to encourage further corporate action.

Some limitations of this study have been identified as the paper progressed. Nevertheless, additional issues we acknowledge include: the subjective nature of self-reporting data on GHG performance; potential language issues, as the questionnaire was in English; limits in the sample size, with a somewhat low response rate; limits in the number of control variables; reliance on a single instrument survey; and the generalisability of the study, given its focus on high emitting industry.

We identify several areas for future research. First, we encourage scholars to examine the drivers of and outcomes from climate change commitment in additional country contexts, including those with markedly different institutional environments, e.g. transition and developing economies. It is also likely that relationships play out differently across industries, for example large combustion versus closer to consumer sectors like retail. Such research could draw insights from scale development undertaken in this paper, and further refine and extend these efforts, with particular scope for development of distinct business and sustainability driver constructs. Investigation of issues of reverse causality between constructs is another potential area for future study. Finally, relationships between drivers and outcomes of commitment to climate change action are dynamic; they change over time, with longitudinal work thus needed.

As discussed in the introduction, the world can no longer afford indecision or half measures if we are to address the challenge of global climate change. Industry has a key role to play in this process. However, if our efforts are to be successful, we need to better understand what drives corporate commitment and action on climate change action. This paper contributes towards this important endeavour.

\section{References}

Backman CA, Verbeke A, Schulz RA. 2015. The Drivers of Corporate Climate Change Strategies and Public Policy A New Resource-Based View Perspective. Business \& Society, doi: $10.1177 / 0007650315578450$.

Bansal P. 2003. From issues to actions: The importance of individual concerns and organizational values in responding to natural environmental issues. Organization Science 14 (5): 510-527 
Bansal P, Roth K. 2000. Why companies go green: A model of ecological responsiveness. Academy of Management Journal 43(4): 717-736.

Bhattacharyya A, Cummings L. 2015. Measuring Corporate Environmental Performance Stakeholder Engagement Evaluation. Business Strategy and the Environment 24: 309-325.

Boiral O, Henri JF, Talbot, D. 2012. Modeling the impacts of corporate commitment on climate change. Business Strategy and the Environment, 21(8): 495-516.

Böttcher CF, Müller M. 2015 Drivers, Practices and Outcomes of Low-carbon Operations: Approaches of German Automotive Suppliers to Cutting Carbon Emissions. Business Strategy and the Environment 24: 477-498.

Cenfetelli RT, Bassellier G. 2009. Interpretation of formative measurement in information systems research. MIS Quarterly 33: 689-708.

Chin WW. 1998. The partial least squares approach to structural equation modelling. In Modern Methods for Business Research, Marcoulides GA (eds): 295-336. Lawrence Erlbaum and Associates: London.

Cummings LS. 2008. Managerial attitudes toward environmental management within Australia, the People's Republic of China and Indonesia. Business Strategy and the Environment 17: 16-29. doi: 10.1002/bse.515.

Dechant K, Altman B. 1994. Environmental leadership: from compliance to competitive advantage. The Academy of Management Executive 8(3): 7-20

Delmas M, Toffel MW. 2004. Stakeholders and environmental management practices: an institutional framework. Business Strategy and the Environment 13: 209-222. doi: $10.1002 /$ bse. 409

Dögl C, Behnam M. 2015. Environmentally Sustainable Development through Stakeholder Engagement in Developed and Emerging Countries. Business Strategy and the Environment 24: 583-600.

Dyllick T, Hockerts K. 2002. Beyond the business case for corporate sustainability. Business Strategy and the Environment 11: 130-141. doi: 10.1002/bse.323

Ervin D, Wu J, Khanna M, Jones C, Wirkkala T. 2013. Motivations and Barriers to Corporate Environmental Management. Business Strategy and the Environment 22: 390-409.

Environment Agency (2015) Business opportunities in a changing climate: Managing impacts and market opportunities. [Accessed 26 ${ }^{\text {th }}$ September 2016]: http://www.acclimatise.uk.com/login/uploaded/resources/EA\%20report.pdf

European Commission. 2014. EU action on climate. [Accessed 26 ${ }^{\text {th }}$ September 2016] http://ec.europa.eu/clima/policies/brief/eu/index_en.htm

European Environment Agency. 2014. The European Pollutant Release and Transfer Register. [Accessed 26 ${ }^{\text {th }}$ September 2016] http://prtr.ec.europa.eu/ 
Haddock-Fraser JE, Tourelle M. 2010. Corporate motivations for environmental sustainable development: exploring the role of consumers in stakeholder engagement. Business Strategy and the Environment 19: 527-542. doi: 10.1002/bse.663.

Hair JFJ, Ringle CM, Sarstedt M. 2011. PLS-SEM: indeed a silver bullet. Journal of Marketing Theory and Practice 19: 135-147.

Halkos GE, Evangelinos KI. 2002. Determinants of environmental management systems standards implementation: evidence from Greek industry. Business Strategy and the Environment 11: 360-375.

Fornell C, Larcker DF. 1981. Evaluating structural equation models with unobservable variables and measurement error. Journal of Marketing Research 18: 31-50.

Furrer B, Hamprecht J. Hoffmann VH. 2012. Much Ado About Nothing? How Banks Respond to Climate Change. Business \& Society 51(1): 62-88.

Henseler J. Fassot, G. 2009. Testing moderating effects in PLS path models: an illustration of available procedures. In Handbook of Partial Least Squares: Concepts, Methods and Applications in Marketing and Related Fields. Vinzi VE, Chin WW, Henseler J, Wang H (eds), Springer-Verlag: Berlin.

Hockerts K. 2015. A Cognitive Perspective on the Business Case for Corporate Sustainability. Business Strategy and the Environment 24: 102-122, doi: 10.1002/bse.1813

González-Benito J, González-Benito O. 2006. A review of determinant factors of environmental proactivity. Business Strategy and the Environment 15: 87-102.

IBT 2016. International Business Times [Accessed 26 ${ }^{\text {th }}$ September 2016] http://www.ibtimes.co.uk/cop21-ban-ki-moon-full-speech-start-paris-climate-change-talks$\underline{1531133}$

IPCC. 2014. Intergovernmental Panel on Climate Change Climate Change 2014 Synthesis Report: Approved Summary for Policymakers. [Accessed 26 ${ }^{\text {th }}$ September 2016] www.ipcc.ch/report/ar5/syr/

Jamali, D. 2010. The CSR of MNC Subsidiaries in Developing Countries: Global, Local, Substantive or Diluted? Journal of Business Ethics 93:181-200

Jayachandran S, Kalaignanam K, Eilert M. 2013. Product and environmental social performance: Varying effect on firm performance. Strategic Management Journal 34(10): $1255-1264$.

Jansson J, Nilsson J, Modig F, Hed Vall G. 2015. Commitment to Sustainability in Small and Medium-Sized Enterprises: The Influence of Strategic Orientations and Management Values. Business Strategy and the Environment doi: 10.1002/bse.1901

Jeswani HK, Wehrmeyer W, Mulugetta Y. 2008. How warm is the corporate response to climate change? Evidence from Pakistan and the UK. Business Strategy and the Environment, 17(1): 46-60. 
Judge WQ, Douglas TJ. 1998. Performance implications of incorporating natural environmental issues into the strategic planning process: An empirical assessment. Journal of Management Studies 35(2): 241-262.

Kassinis G, Vafeas N. 2006. Stakeholder pressures and environmental performance. Academy of Management Journal, 49(1): 145-159.

Kolk A, Pinkse J. 2005. Business Responses to Climate Change: Identifying Emergent Strategies. California Management Review 47(3): 6-20.

Kostova T, Roth K. 2002. Adoption of organizational practices by subsidiaries of multinational corporations: Institutional and relational effects. Academy of Management Journal 45: 215233.

Lee, SY. 2012. Corporate Carbon Strategies in Responding to Climate Change. Business Strategy and the Environment 21: 33-48.

Lee S, Klassen RD. 2015. Firms' Response to Climate Change: The Interplay of Business Uncertainty and Organizational Capabilities. Business Strategy and the Environment doi: 10.1002/bse. 1890 .

Leisen A. 2015. Climate Change and Financial Market Efficiency, Business \& Society 54(4): 511-539.

López-Gamero MD, Molina-Azorín JF, Claver-Cortés E. 2010. The potential of environmental regulation to change managerial perception, environmental management, competitiveness and financial performance. Journal of Cleaner Production 18(10): 963-974.

Matten D, Moon J. 2008. "Implicit" and "Explicit" CSR: A Conceptual Framework for a Comparative Understanding of Corporate Social Responsibility. Academy of Management Review 33(2): 404-424.

Okereke C. 2007. An exploration of motivations, drivers and barriers to carbon management: the UK FTSE 100. European Management Journal 25(6): 475-486.

Pinkse J, Kolk A. 2007. Multinational Corporations and Emissions Trading: Strategic Responses to New Institutional Constraints. European Management Journal 25(6): 441-452

Pinkse J, Kolk A. 2010. Challenges and trade-offs in corporate innovation for climate change. Business Strategy and the Environment 19: 261-272.

Porter ME, van der Linde C. 1995. Green and competitive: ending the stalemate. Harvard Business Review 73: 120-134.

Porter ME, Reinhardt FL. 2007. A Strategic Approach to Climate. Harvard Business Review 85: $22-26$. 
Roy MJ, Boiral O, Lagacé D. 2001. Environmental commitment and manufacturing excellence: a comparative study within Canadian industry. Business Strategy and the Environment 10: 257-268. doi: 10.1002/bse.304

Schultz K, Williamson P. 2005. Gaining competitive advantage in a carbon-constrained world: Strategies for European business. European Management Journal 23: 383-391

Scott WR. 2001. Institutions and organizations (2nd ed.) Thousand Oaks, CA: Sage.

Sprengel DC, Busch T. 2011. Stakeholder engagement and environmental strategy: The case of climate change. Business Strategy and the Environment, 20(6): 351 - 364

Sullivan R, Gouldson AP. 2016. The governance of corporate responses to climate change: An International Comparison, Business Strategy and the Environment, ISSN 0964-4733.

Wakabayashia M, Arimurac TH. 2016. Voluntary agreements to encourage proactive firm action against climate change: an empirical study of industry associations' voluntary action plans in Japan, Journal of Cleaner Production 112(4): 2885-2895

Walsh, P. R., and Dodds, R. (2017) Measuring the Choice of Environmental Sustainability Strategies in Creating a Competitive Advantage. Business Strategy and the Environment 26: 672-687.

Williams S, Schaefer A. 2013. Small and Medium-Sized Enterprises and Sustainability: Managers' Values and Engagement with Environmental and Climate Change Issues. Business Strategy and the Environment 22: 173-186. doi: 10.1002/bse.1740.

Winn M, Kirchgeorg M, Griffiths A, Linnenluecke MK, Günther E. 2011. Impacts from climate change on organizations: a conceptual foundation. Business Strategy and the Environment 20: 157-173.

World Resources Institute. 2014. Climate Analysis Indicators Tool (CAIT) 2.0 [Accessed 26 ${ }^{\text {th }}$ September 2016] http://cait2.wri.org

Yalabik B, Fairchild RJ. 2011. Customer, regulatory, and competitive pressure as drivers of environmental innovation. International Journal of Production Economics 131(2): 519-527. 


\section{Appendix A: Descriptive Statistics}

Table A.1: Sector

\begin{tabular}{lcc}
\hline Sector & Number of facilities & Proportion \\
\hline Large combustion plants & 81 & $87 \%$ \\
Chemical facilities & 12 & $13 \%$ \\
\hline
\end{tabular}

Table A.2: Facility size

\begin{tabular}{lcc}
\hline Number of employees & Respondents & Proportion \\
\hline$<100$ & 33 & $36 \%$ \\
100 to 199 & 12 & $13 \%$ \\
200 to 299 & 11 & $12 \%$ \\
300 to 399 & 3 & $3 \%$ \\
400 to 499 & 10 & $11 \%$ \\
$\geq 500$ & 24 & $26 \%$ \\
\hline
\end{tabular}

Table A.3: Country

\begin{tabular}{lcc}
\hline Country & Respondents & Proportion \\
\hline EU-15 & 52 & $56 \%$ \\
Other & 41 & $44 \%$ \\
\hline
\end{tabular}

Table A.4: $\mathrm{CO}_{2}$ emissions

\begin{tabular}{lcc}
\hline Annual CO 2 emissions & Respondents & Proportion \\
\hline$\leq 100,000$ tonnes & 15 & $16 \%$ \\
100,001 to 200,000 tonnes & 15 & $16 \%$ \\
200,001 to 500,000 tonnes & 21 & $22 \%$ \\
500,001 to 3,000,000 tonnes & 30 & $32 \%$ \\
$3,000,001$ to 30 million tonnes & 11 & $12 \%$ \\
$>30$ million tonnes & 1 & $1 \%$ \\
\hline
\end{tabular}

Table A.5: Respondent's role in the facility

\begin{tabular}{lcc}
\hline Respondent's role & Respondents & Proportion \\
\hline Chief Executive Officer / Chief Operating Officer & 3 & $3 \%$ \\
General manager & 1 & $1 \%$ \\
Plant manager / Production manager & 4 & $4 \%$ \\
Quality manager & 1 & $1 \%$ \\
Environmental manager & 56 & $61 \%$ \\
Other manager & 5 & $5 \%$ \\
Other: Including joint environmental and health \& safety / & 22 & $24 \%$ \\
$\quad$ quality roles, engineering / environmental engineering \\
$\quad$ roles
\end{tabular}




\section{Appendix B: Scale Items}

Table B.1 Scale items with item weights for the formative scales and item loadings for the reflective scale

\begin{tabular}{|c|c|c|}
\hline \multicolumn{3}{|c|}{ Formative variables } \\
\hline Scale & Items & Weights \\
\hline \multirow[t]{9}{*}{ Business drivers } & Marketing / advertising opportunity & $-.210(\mathrm{~ns})$ \\
\hline & $\begin{array}{l}\text { Reducing production costs (e.g. energy and carbon } \\
\text { costs) }\end{array}$ & $.065(\mathrm{~ns})$ \\
\hline & $\begin{array}{l}\text { Caring for shareholders' investment and increasing } \\
\text { shareholder value }\end{array}$ & $-.037(\mathrm{~ns})$ \\
\hline & Increasing profits & $-.248 *$ \\
\hline & Customer requirement & $-.037(\mathrm{~ns})$ \\
\hline & Greater access to capital (e.g. bank loans) & $-.248(\mathrm{~ns})$ \\
\hline & $\begin{array}{l}\text { Increasing revenue through innovation (e.g. } \\
\text { developing energy-efficient products) }\end{array}$ & $.456^{* * *}$ \\
\hline & $\begin{array}{l}\text { Reducing the risk of physical damage from the } \\
\text { effects of climate change (e.g. flooding) }\end{array}$ & $.302 * *$ \\
\hline & $\begin{array}{l}\text { Developing credibility and leverage to influence } \\
\text { climate policy }\end{array}$ & $.667 * * *$ \\
\hline \multirow[t]{7}{*}{ Sustainability drivers } & $\begin{array}{l}\text { Public demonstration of environmental } \\
\text { stewardship }\end{array}$ & $.288 *$ \\
\hline & Reducing environmental impacts and pollution & $.274 *$ \\
\hline & Improving regulatory compliance & $-.316(\mathrm{~ns})$ \\
\hline & $\begin{array}{l}\text { Top managers' social responsibility and ethical } \\
\text { concerns }\end{array}$ & .008 (ns) \\
\hline & Employee involvement & $.271 *$ \\
\hline & Corporate headquarters requirement & $.228(\mathrm{~ns})$ \\
\hline & $\begin{array}{l}\text { Demonstrating environmental leadership in our } \\
\text { industry }\end{array}$ & $.216(\mathrm{~ns})$ \\
\hline \multirow[t]{14}{*}{ Stakeholder pressure } & Corporate headquarters & $.249 * *$ \\
\hline & Public, citizens & $.061(\mathrm{~ns})$ \\
\hline & Environmental groups & $.219 * *$ \\
\hline & Customers & $-.123(\mathrm{~ns})$ \\
\hline & $\begin{array}{l}\text { Government and lawmakers / legislators (e.g. laws, } \\
\text { regulations) }\end{array}$ & $.606 * *$ \\
\hline & $\begin{array}{l}\text { Local or national authorities / regulators (e.g. permit } \\
\text { requirements, enforcement) }\end{array}$ & $-.210(\mathrm{~ns})$ \\
\hline & Financial institutions and insurance companies & $-.035(\mathrm{~ns})$ \\
\hline & Stockholders & $.031(\mathrm{~ns})$ \\
\hline & Employees & $.345 * *$ \\
\hline & Suppliers & $-.019(\mathrm{~ns})$ \\
\hline & Competitors & $-.008(\mathrm{~ns})$ \\
\hline & Company owners & $.020(\mathrm{~ns})$ \\
\hline & Facility management & $.231 *$ \\
\hline & Media & $-.182(\mathrm{~ns})$ \\
\hline GHG performance & $\begin{array}{l}\text { Compliance with environmental regulations and } \\
\text { permits }\end{array}$ & $.082(\mathrm{~ns})$ \\
\hline
\end{tabular}




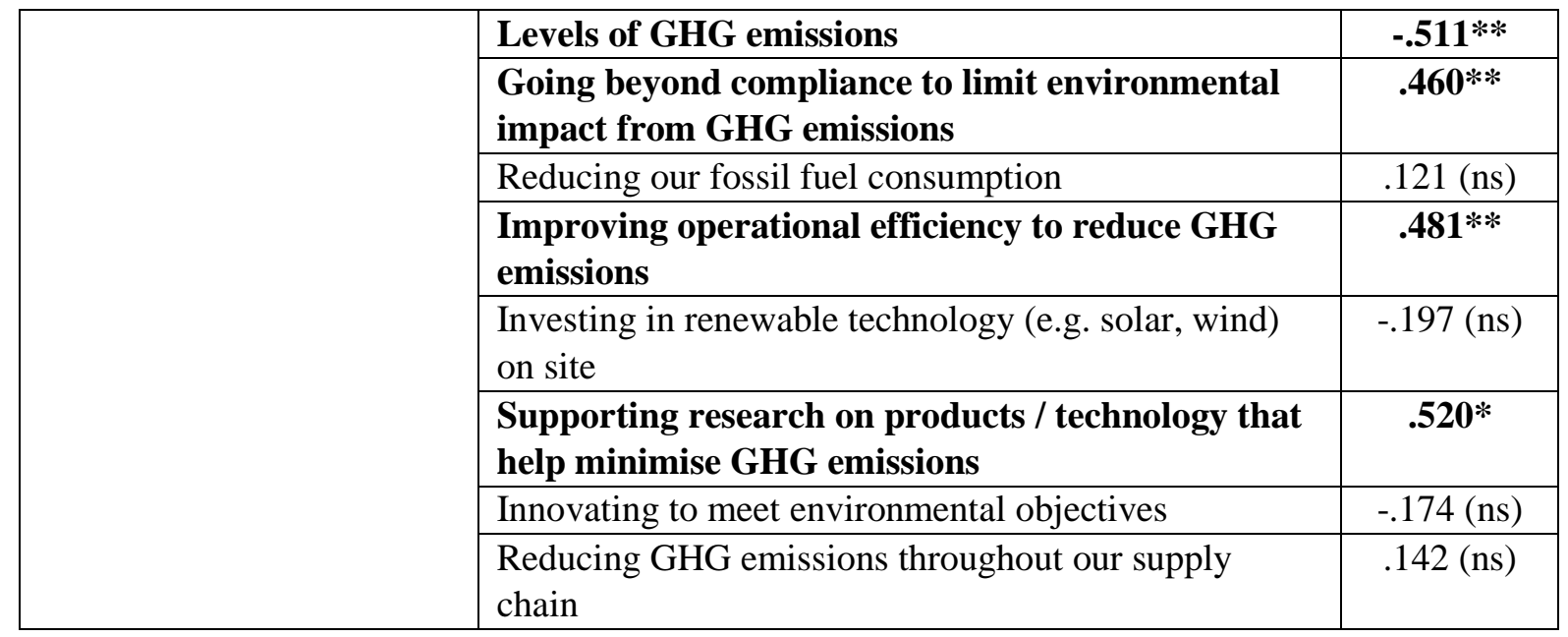

\begin{tabular}{|c|c|c|}
\hline \multicolumn{3}{|c|}{ Reflective variable (9 items) } \\
\hline Scale & Items & Loadings \\
\hline \multirow[t]{9}{*}{$\begin{array}{l}\text { Commitment to } \\
\text { climate change action }\end{array}$} & $\begin{array}{l}\text { Our top managers are concerned about global } \\
\text { warming }\end{array}$ & $.761 * * *$ \\
\hline & $\begin{array}{l}\text { Our facility has a proactive strategy to cut GHG } \\
\text { emissions }\end{array}$ & $.763 * * *$ \\
\hline & $\begin{array}{l}\text { We publish information about our facility's GHG } \\
\text { emissions }\end{array}$ & $.560 * * *$ \\
\hline & $\begin{array}{l}\text { Our facility has an environmental policy that includes } \\
\text { a commitment to reduce GHGs }\end{array}$ & $.805 * * *$ \\
\hline & $\begin{array}{l}\text { GHG performance is explicitly considered in the } \\
\text { strategic planning process }\end{array}$ & $.820 * * *$ \\
\hline & $\begin{array}{l}\text { We benchmark our GHG performance against that of } \\
\text { other facilities in our sector }\end{array}$ & $.653 * * *$ \\
\hline & $\begin{array}{l}\text { Climate change action is an important element of our } \\
\text { company culture }\end{array}$ & $.843 * * *$ \\
\hline & $\begin{array}{l}\text { GHG targets are integrated into our management } \\
\text { control systems }\end{array}$ & $.779 * * *$ \\
\hline & $\begin{array}{l}\text { We give importance to GHG emissions across our } \\
\text { supply chain (e.g. raw material supply) }\end{array}$ & $.618 * * *$ \\
\hline
\end{tabular}

